\title{
Farber disease
}

INSERM

\section{Source}

INSERM. (1999). Orphanet: an online rare disease and orphan drug data base. Farber disease. ORPHA:333

A subcutaneous tissue disease characterized by a spectrum of clinical signs rang ing from the classical triad of painful and progressively deformed joints, subcutaneous nodules, and progressive hoarseness (due to laryngeal involvement) that presents in infancy, to varying phenotypes with respiratory and neurologic involvement. 